\title{
Quantitative analysis of immunoglobulin E reactivity profiles in patients allergic or sensitized to natural rubber latex (Hevea brasiliensis)
}

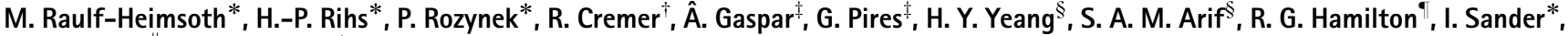 \\ M. Lundberg ${ }^{\|}$and T. Brüning* \\ *BGFA-Research Institute of Occupational Medicine - German Social Accident Insurance, Ruhr-University Bochum, Bochum, Germany, ${ }^{\dagger}$ Children's Hospital, Cologne, \\ Germany, ${ }^{\ddagger}$ Immunoallergy Department, Dona Estefânia Hospital, Lisbon, Portugal, ${ }^{\S}$ Rubber Research Institute of Malaysia (RRIM), Kuala Lumpur, Malaysia, ${ }^{\circledR}$ Johns \\ Hopkins University School of Medicine, Baltimore, MD, USA and "MIAB, Uppsala, Sweden
}

\section{Clinical and Experimental Allergy}

Correspondence:

Raulf-Heimsoth, Monika, PhD, Allergology/Immunology, BGFA Forschungsinstitut für Arbeitsmedizin der Deutschen Gesetzlichen Unfallversicherung, Institut der RuhrUniversität Bochum, Bürkle-de-laCamp-Platz 1, 44789 Bochum, Germany. E-mail: raulf@bgfa.de

\begin{abstract}
Summary
Background Characterized native and recombinant Hevea brasiliensis ( $\mathrm{rHev}$ b) natural rubber latex (NRL) allergens are available to assess patient allergen sensitization profiles.

Objective Quantification of individual IgE responses to the spectrum of documented NRL allergens and evaluation of cross-reactive carbohydrate determinants (CCDs) for more definitive diagnosis.

Methods Sera of 104 healthcare workers (HCW; 51 German, 21 Portuguese, 32 American), 31 spina bifida patients (SB; 11 German, 20 Portuguese) and 10 Portuguese with multiple surgeries (MS) were analysed for allergen-specific IgE antibody (sIgE) to NRL, single Hev b allergens and CCDs with ImmunoCAP ${ }^{\mathrm{TM}}$ technology.

Results In all patient groups $\mathrm{rHev}$ b 5-sIgE concentrations were the most pronounced. Hev b 2, 5, 6.01 and 13 were identified as the major allergens in HCW and combined with Hev b 1 and Hev b 3 in SB. In MS Hev b 1 displayed an intermediate relevance. Different slgE antibody levels to native Hevea brasiliensis (nHev b) 2 and $\mathrm{rHev}$ b 6.01 allowed discrimination of SB with clinical relevant latex allergy vs. those with latex sensitization. Sensitization profiles of German, Portuguese and American patients were equivalent. rHev b 5, 6.01 and nHev b 13 combined detected $100 \%$ of the latex-allergic HCW and $80.1 \%$ of the SB. Only $8.3 \%$ of the sera showed sIgE response to CCDs.

Conclusions Hev b 1, 2, 5, 6.01 and 13 were identified as the major Hev b allergens and they should be present in standardized latex extracts and in vitro allergosorbents. CCDs are only of minor relevance in patients with clinical relevant latex allergy. Component-resolved diagnostic analyses for latex allergy set the stage for an allergen-directed immunotherapy strategy.
\end{abstract}

Keywords in vitro diagnostic analysis, latex allergy, recombinant latex allergens, sensitization profile

Submitted 15 December 2006; revised 13 August 2007; accepted 17 August 2007

\section{Introduction}

During the last decade considerable effort has been expended to document the molecular characteristics of Hevea brasiliensis (Hev b) latex allergens due to the high prevalence of latex allergy among well-defined risk groups such as healthcare workers (HCW) and patients with spina bifida (SB). Of the more than 240 natural rubber latex (NRL) polypeptides, 13 latex proteins (Hev b
1-13) have been officially recognized as allergens by the International Union of Immunological Societies (IUIS) [1-5]. Hev b 1-13 have been isolated by conventional purification methods and/or by molecular cloning techniques. The advantage of recombinant proteins in contrast to native proteins is the reproducible large-scale production of a single isoform of high quality. Most of the recombinant latex allergens have been produced in Escherechia coli due to absence of post-translational 
Table 1. Demographics and clinical data of the study subjects

\begin{tabular}{|c|c|c|c|c|c|}
\hline \multirow[b]{2}{*}{ Patients } & \multirow[b]{2}{*}{ Gender } & \multirow{2}{*}{$\begin{array}{l}\text { Atopics } \\
\text { (percentage; number } \\
\text { of patients with LFS) }\end{array}$} & \multirow{2}{*}{$\begin{array}{l}\text { Age (years) mean } \pm \text { SD } \\
\text { (median; range) }\end{array}$} & \multicolumn{2}{|c|}{ Mean \pm SD (median; range) } \\
\hline & & & & Total IgE (kU/L) & Latex-specific IgE* \\
\hline German SB $(n=11)^{\dagger}$ & $\begin{array}{l}\text { Seven males } \\
\text { four females }\end{array}$ & 4 (36.4\%; 1 with LFS) & $\begin{array}{l}10.4 \pm 5.2 \\
(9 ; 3-21)\end{array}$ & $\begin{array}{l}394.5 \pm 524.8 \\
\quad(228 ; 12.8-1800)\end{array}$ & $\begin{array}{l}29.5 \pm 28.9 \\
\quad(17.8 ; 0.85 \text { to }>100)\end{array}$ \\
\hline Portuguese SB $(n=20)^{\ddagger}$ & $\begin{array}{l}\text { Seven males } \\
13 \text { females }\end{array}$ & 9 (45\%; 1 with LFS) & $\begin{array}{l}10.1 \pm 2.75 \\
\quad(10 ; 6-15)\end{array}$ & $\begin{array}{l}430.1 \pm 470.4 \\
\quad(294 ; 5.5 \text { to }>2000)\end{array}$ & $\begin{array}{l}18.7 \pm 19.7 \\
\quad(11.7 ; 0.66-65.4)\end{array}$ \\
\hline $\operatorname{MS}(n=10)$ & $\begin{array}{l}\text { Five males } \\
\text { five females }\end{array}$ & 6 (60\%; 1 with LFS) & $\begin{array}{l}16.7 \pm 18.1 \\
\quad(9.5 ; 3-51)\end{array}$ & $\begin{array}{l}266.7 \pm 204.4 \\
\quad(244 ; 20-601)\end{array}$ & $\begin{array}{l}6.4 \pm 5.3 \\
(6.3 ; 0.51-14.4)\end{array}$ \\
\hline German HCW ( $n=51)$ & $\begin{array}{l}\text { Six males } \\
45 \text { females }\end{array}$ & 40 (78.4\%; 20 with LFS) & $\begin{array}{l}32.3 \pm 8.2 \\
\quad(30 ; 19-58)\end{array}$ & $\begin{array}{l}432.9 \pm 516.5 \\
\quad(243 ; 22.8 \text { to }>2000)\end{array}$ & $\begin{array}{l}24.4 \pm 30.2 \\
\quad(11.8 ; 0.78 \text { to }>100)\end{array}$ \\
\hline Portuguese HCW ( $n=21)$ & $\begin{array}{l}\text { One male } \\
20 \text { females }\end{array}$ & 15 (71\%; 14 with LFS) & $\begin{array}{l}37.4 \pm 8.4 \\
\quad(38 ; 24-54)\end{array}$ & $\begin{array}{l}560.6 \pm 1118.6 \\
\quad(210 ; 18.1 \text { to }>2000)\end{array}$ & $\begin{array}{l}17.5 \pm 27.2 \\
\quad(4.4 ; 0.35 \text { to }>100)\end{array}$ \\
\hline American HCW $(n=32)$ & $\begin{array}{l}\text { Four males } \\
28 \text { females }\end{array}$ & 22 (69\%; 8 with LFS) & $\begin{array}{l}35.3 \pm 8.7 \\
\quad(36 ; 19-58)\end{array}$ & $\begin{array}{l}434.2 \pm 503.1 \\
\quad(186 ; 12.5-1831)\end{array}$ & $\begin{array}{l}14.9 \pm 22.8 \\
\quad(4.9 ; 0.74 \text { to }>100)\end{array}$ \\
\hline
\end{tabular}

*k82s (supplemented; with rHev b 5).

${ }^{\dagger} \mathrm{SB}$ from Germany ( $n=11$; with symptoms: 7, without symptoms: 4).

${ }^{\ddagger}$ SB from Portugal ( $n=20$; with symptoms: 12 , without symptoms: 8 ).

LFS, latex-fruit syndrome; SB, spina bifida; HCW, health care workers; MS, multiple surgeries; rHev b, recombinant Hevea brasiliensis.

modifications [6-8], but they have had to be validated against native proteins to confirm bioequivalency in terms of allergenic reactivity [9].

In contrast to the established Hev $b$ allergens, the role of cross-reactive carbohydrate determinants (CCDs) and glycosylation as epitopes involved in latex allergenicity has remained unclarified [5].

Because of a remarkable success of preventive avoidance practices, the epidemic of latex allergy in the healthcare field of industrialized countries appears to have subsided [10, 11]. However, in non-healthcare areas and throughout less-industrialized countries, latex sensitization remains a serious clinical problem [12]. Because of this remaining concern, improved diagnostic and management methods, possibly involving immunotherapy, remain important areas of investigation [13, 14].

Questions still persist with regard to the reagents used in the diagnosis of latex allergy. Crude non-ammoniated latex extracts containing mixtures of allergenic and nonallergenic proteins have been used to prepare puncture skin-testing reagents and allergosorbents used in in vitro and in vivo analyses, respectively. The variable quality of the natural raw material remains a source of concern. Thus, we and others have focused on the development of component-resolved strategies for the diagnosis and management of human allergic disease $[15,16]$.

The objective of this study was to characterize individual IgE antibody responses to single recombinant and native latex allergens in a group of latex-allergic HCW, in latex-sensitized or latex-allergic patients with SB and in latex-allergic patients with multiple surgeries (MS) from multiple countries using a quantitative system that allowed latex-specific IgE mapping. Additionally, markers of CCDs [horseradish peroxidase (HRP) and bromelain] were used to ascertain the importance of glycoepitopes for IgE binding in patients with proven latex contact. Finally, the available ImmunoCAPs ${ }^{\mathrm{TM}}$ with or without recombinant Hev b5 (rHev b 5) were used to determine the total latex-specific IgE. These responses were then compared with a mixture of four recombinant single latex allergens ( $\mathrm{rHev} \mathrm{b} \mathrm{1,} \mathrm{5,} \mathrm{6.01,} \mathrm{8)} \mathrm{to} \mathrm{assess} \mathrm{the} \mathrm{utility} \mathrm{of} \mathrm{this} \mathrm{panel} \mathrm{as} \mathrm{a}$ latex allergen screen.

\section{Materials and methods}

\section{Patients}

Sera of 104 HCW, 31 SB patients and 10 patients with MS were collected. Sensitization (IgE anti-NRL positivity) was confirmed in all patients using the NRL ImmunoCAP ${ }^{\mathrm{TM}}$ allergosorbent. Fifty-one sera were derived from NRL occupationally exposed German HCW (Table 1; 32 hospital staff nurses, 13 physician's or dentist's assistants, four physicians, one medical technician and one midwife). These individuals exhibited a range of symptoms including asthma, rhinitis, conjunctivitis, eczema and urticaria following latex exposure. They also had a positive NRL skin prick test (SPT using the Stallergen NRL extract and an in-house extract prepared from NRL C-serum) and a positive challenge test to latex gloves. The latex glove challenge test was performed using a standardized protocol in a provocation chamber in which the patient handled a progressively increasing number of powdered latex gloves (Unigloves Malaysia), starting with two gloves (one pair) for $5 \mathrm{~min}$. The patient continued handling up to a maximum of 20 gloves over a period of $30 \mathrm{~min}$ until symptoms were observed. In this manner, severe asthmatic or anaphylactic reactions were prevented. The test 
was defined as positive, if the forced expiratory volume in $1 \mathrm{~s}$ dropped $20 \%$ below the baseline or if the specific airway $\mathrm{sG}_{\mathrm{aw}}$ dropped by at least $50 \%$ in comparison with the baseline value and an absolute value of $\leqslant 0.5$ (kPa s) was obtained [17].

The 21 sera derived from Portuguese HCW suffered from NRL-related symptoms comparable with the German HCW; however, four of them had anaphylaxis following NRL exposure. All Portuguese HCW had a positive NRL SPT (using Stallergen, Leti and Alk-Abello extracts) and a positive challenge test to latex gloves. Thirty-two sera were obtained from occupationally NRL-exposed American HCW (17 hospital staff nurses, six lab technicians, one respiratory therapist, one radiology technician, one pharmacy technician, two physicians, one dentist and three other hospital staff members). Thirteen suffered from symptoms such as eczema or urticaria, conjunctivitis and rhinitis following latex glove exposure. Nine experienced eczema or urticaria, conjunctivitis, rhinitis and asthma. Another nine manifested eczema or urticaria and conjunctivitis and one had additional symptoms of anaphylaxis. Twenty-one American HCW were Caucasian, four were Afroamericans, four were Hispanic and three were Asians. All American HCW were puncture skin test positive with an investigational non-ammoniated latex from Malaysia that was prepared by Greer Laboratories.

Serum was collected from 20 children and a young adult with SB from Portugal and 11 German SB patients. Nineteen of the 31 SB had symptoms related to NRL exposure that included rhinitis, angio-oedema, conjunctivitis, asthma and urticaria. In five cases, isolated urticaria occurred and there was case of latex-induced anaphylaxis. The remaining 12 SB patients were only sensitized (IgE antibody positive) to NRL without any apparent clinical symptoms. All SB patients underwent between two and 30 surgeries. Forty-two percent of all SB patients were atopics and two suffered from the latex-fruit syndrome (LFS). Ten sera were obtained from Portuguese patients without SB but who had undergone MS (3-16; median 4.5) (MS) (Table 1). All of these MS patients suffered from NRL-related symptoms that included urticaria, conjunctivitis, rhinitis, angio-oedema and in three cases anaphylaxis. All surgeries had been performed with NRL devices (e.g. gloves and other medical supplies) containing NRL before implementation of NRL avoidance measures. None of the patients had received immunotherapy or corticosteroid therapy at the time of the study. Informed consent was obtained from all patients or their parents before collecting their blood.

\section{Immunoglobulin E antibody analyses}

Serological testing was performed using the Immuno$\mathrm{CAP}^{\mathrm{TM}} 100$ system (Phadia, Uppsala, Sweden). All sera were analysed for latex-specific IgE using the latex
ImmunoCAP ${ }^{\mathrm{TM}} \mathrm{k} 82 \mathrm{~s}$ (supplemented for $\mathrm{rHev} \mathrm{b}$ 5). Additionally, sera from the German HCW were analysed using the k82 ImmunoCAP ${ }^{\mathrm{TM}}$ (without $\mathrm{rHev}$ b 5 supplemenation) and a 'multi-allergen' ImmunoCAP ${ }^{\mathrm{TM}}$ prepared with a mixture of four recombinant latex allergens ( $\mathrm{rHev}$ b 1, 5, 6.01, 8; rHev b-mix). ImmunoCAPs ${ }^{\mathrm{TM}}$ containing HRP (Ro400) and bromelain (k202) were chosen to detect CCD-specific IgE. sIgE values $>0.35 \mathrm{kUa} / \mathrm{L}$ were considered positive. Sera of 10 non-allergic control patients and containing no sIgE to NRL displayed negative results to the single allergens tested (data not shown). IgE inhibition experiments were performed with $\mathrm{k} 82 \mathrm{~s}$ ImmunoCAP ${ }^{\mathrm{TM}}$ as the solid phase and 10 $\mu \mathrm{L}$ HRP (10 mg/mL, Sigma, Taufkirchen, Germany) as the inhibitor added to $50 \mu \mathrm{L}$ sera. Inhibition $>20 \%$ was defined as relevant.

\section{Native and recombinant latex allergens}

Individual recombinant ( $\mathrm{rHev}$ b 1, 2, 3, 5, 6.01, 7.02, 8, 9, $10,11,12$ ) and native (nHev b 2, nHev b 13 and in few cases $n H e v$ b 4) latex allergens were each coupled to separate ImmunoCAPs ${ }^{\mathrm{TM}}$. The three native latex allergens were prepared at the Rubber Research Institute in Malaysia $[18,19]$, purified and coupled to streptavidin Immuno$\mathrm{CAP}^{\mathrm{TM}}$ as described [20]. All recombinant latex allergens were produced in $E$. coli in fusion with maltose-binding protein (MBP) [6-8, 21-23]. For this reason, MBP was coupled to a separate ImmunoCAP ${ }^{\mathrm{TM}}$ to serve as a control.

\section{Statistical analysis}

The Kruskal-Wallis test was used for the unpaired comparison between the different groups. Statistical tests were performed using the StatXact-3 software package (CytelSoftware, Corp., Cambridge, MA, USA). Two-sided test $P$-values were calculated and $P$-values of $<0.05$ were considered significant. Pearson's correlation coefficients were used to evaluate the correlation between variables.

\section{Results}

\section{Latex allergen recognition patterns among different patient groups}

Spina bifida patients. The demographics and clinical data for the study subjects are presented in Table 1. Table 2a presents the prevalence and quantitative levels of specific IgE antibody to individual latex allergens in sera from the SB patients (11 German and 20 Portuguese). The prevalence of rHev b 1-specific IgE was the highest in both groups. This was followed by reactivity to a constellation of allergens including $\mathrm{nHev}$ b 2, rHev b 3, rHev b 5, rHev b 6.01 and nHev b 13-specific IgE. Reactivity to $\mathrm{rHev}$ b 7.02, rHev b 8, rHev b 11 and rHev b 12 was low (6.4-19\% prevalence). All SB sera contained no detectable IgE antibody reactive with MBP (data not shown) and $\mathrm{rHev}$ b 2, 9 and 10. 
Table 2a. Prevalence and quantitative levels of specific IgE levels to individual latex allergens in German ( $n=11)$ and Portuguese $(n=20)$ spina bifida patients and in patients with multiple surgeries (MS) $(n=10)$

\begin{tabular}{|c|c|c|c|c|c|c|}
\hline \multirow[b]{2}{*}{ Allergen } & \multicolumn{2}{|l|}{ SB (German) } & \multicolumn{2}{|l|}{ SB (Portuguese) } & \multicolumn{2}{|l|}{ MS patients } \\
\hline & $\begin{array}{l}\text { No. of patients } \\
\text { with sIgE } \\
>0.35 \mathrm{kUa} / \mathrm{L}(\%)\end{array}$ & $\begin{array}{l}\text { Mean } \pm \text { SD of } \\
\text { sIgE }>0.35 \mathrm{kUa} / \mathrm{L} \\
\text { (median; range) }\end{array}$ & $\begin{array}{l}\text { No. of patients } \\
\text { with sIgE } \\
>0.35 \mathrm{kUa} / \mathrm{L}(\%)\end{array}$ & $\begin{array}{l}\text { Mean } \pm \text { SD of } \\
\text { sIgE }>0.35 \mathrm{kUa} / \mathrm{L} \\
\text { (median; range) }\end{array}$ & $\begin{array}{l}\text { No. of patients } \\
\text { with sIgE } \\
>0.35 \mathrm{kUa} / \mathrm{L}(\%)\end{array}$ & $\begin{array}{l}\text { Mean } \pm \text { SD of } \\
\text { sIgE }>0.35 \mathrm{kUa} / \mathrm{L} \\
\text { (median; range) }\end{array}$ \\
\hline rHev b 1 & $11(100)$ & $\begin{array}{l}14.0 \pm 17.6 \\
(7.9 ; 0.47-48.8)\end{array}$ & $14(70)$ & $\begin{array}{l}5.2 \pm 8.38 \\
\quad(2.34 ; 0.74-33.1)\end{array}$ & $3(30)$ & $\begin{array}{l}3.98 \pm 5.3 \\
\quad(1.45 ; 0.39-10.1)\end{array}$ \\
\hline nHev b 2 & $6(75)^{*}$ & $\begin{array}{l}3.4 \pm 1.97 \\
\quad(3.7 ; 1.07-5.48)\end{array}$ & $12(63.2)^{\dagger}$ & $\begin{array}{l}4.9 \pm 4.4 \\
\quad(3.7 ; 0.45-13.95)\end{array}$ & $6(60)$ & $\begin{array}{l}1.25 \pm 1.49 \\
\quad(0.47 ;-0.38 \text { to } 4.11)\end{array}$ \\
\hline rHev b 3 & $8(72.7)$ & $\begin{array}{l}24.9 \pm 24.3 \\
\quad(15.2 ; 0.47-60.7)\end{array}$ & $10(50)$ & $\begin{array}{l}13.0 \pm 28.4 \\
\quad(3.7 ; 0.55-92.9)\end{array}$ & $2(20)$ & $\begin{array}{l}0.45 \pm 0.08 \\
\quad(0.45 ; 0.39-0.51)\end{array}$ \\
\hline rHev b 5 & $5(45.5)$ & $\begin{array}{l}19.9 \pm 16.6 \\
\quad(14.7 ; 1.3-45.2)\end{array}$ & $11(55)$ & $\begin{array}{l}37.1 \pm 36.5 \\
\quad(22.1 ; 0.37 \text { to }>100)\end{array}$ & $4(40)$ & $\begin{array}{l}10.1 \pm 6.4 \\
\quad(8.03 ; 5.15-19.0)\end{array}$ \\
\hline rHev b 6.01 & $6(54.5)$ & $\begin{array}{l}14.9 \pm 16.55 \\
(9.25 ; 0.64-42.1)\end{array}$ & $9(45)$ & $\begin{array}{l}10.6 \pm 11.7 \\
\quad(4.6 ; 1.02-36.4)\end{array}$ & $3(30)$ & $\begin{array}{l}6.8 \pm 8.8 \\
\quad(2.57 ; 0.9-16.9)\end{array}$ \\
\hline rHev b 7.02 & $1(11.1)^{\ddagger}$ & 5.57 & $5(25)$ & $\begin{array}{l}2.7 \pm 2.5 \\
\quad(2.3 ; 0.38-5.8)\end{array}$ & 0 & - \\
\hline rHev b 8 & $0(0)$ & - & $2(10)$ & $\begin{array}{l}1.1 \pm 0.86 \\
\quad(1.07 ; 0.46-1.67)\end{array}$ & 0 & - \\
\hline rHev b 9 & $0(0)$ & - & $0(0)$ & - & 0 & - \\
\hline rHev b 10 & $0(0)$ & - & $0(0)$ & - & 0 & - \\
\hline rHev b 11 & $3(33.3)^{\ddagger}$ & $\begin{array}{l}6.2 \pm 7.82 \\
\quad(2.7 ; 0.8-12.5)\end{array}$ & $2(10)$ & $\begin{array}{l}2.2 \pm 1.6 \\
\quad(2.2 ; 1.04-3.3)\end{array}$ & 0 & - \\
\hline rHev b 12 & $1(11.1)^{\ddagger}$ & 0.54 & $4(23.5)$ & $\begin{array}{l}0.6 \pm 0.07 \\
\quad(0.58 ; 0.47-0.63)\end{array}$ & $1(10)$ & 0.59 \\
\hline nHev b 13 & $6(75)^{*}$ & $\begin{array}{l}4.7 \pm 4.9 \\
\quad(2.5 ; 0.53-12.5)\end{array}$ & $12(63.2)^{\dagger}$ & $\begin{array}{l}3.4 \pm 2.5 \\
\quad(3.2 ; 0.6-8.5)\end{array}$ & $5(50)$ & $\begin{array}{l}1.3 \pm 1.0 \\
\quad(0.81 ; 0.43-2.34)\end{array}$ \\
\hline
\end{tabular}

${ }^{*} n=8 ;{ }^{\dagger} n=19 ;{ }^{\ddagger} n=9$.

rHev b, recombinant Hevea brasiliensis; SB, spina bifıda; sIgE, allergen-specific IgE antibody; nHev b, native Hevea brasiliensis.

Serum from only one Portuguese non-atopic SB patient (NRL-sIgE: $0.66 \mathrm{kUa} / \mathrm{L}$ and total IgE: $7.96 \mathrm{kUa} / \mathrm{L}$ ) who had four surgeries and suffered from latex-related angiooedema had undectectable IgE antibody to all 12 of the $\mathrm{Hev}$ b-allergen specificities tested. Additional testing with $\mathrm{nHev}$ b 4 demonstrated an apparent exclusive sIgE response to this allergen, in a concentration similar to NRL $(0.59 \mathrm{kUa} /$ L; data not shown in table). All the other 30 SB sera responded to a mean of four individual NRL allergens (range: 1-8 Hev b specificities per serum).

The correlation between NRL-sIgE concentrations in $\mathrm{kUa} / \mathrm{L}$ and the qualitative number of allergens specificities that were positive in each subject was highly significant $(r=0.65 ; P<0.0001)$. In contrast, the correlation between the number of surgeries and the total number of IgE antiHev b specificities per serum or the composite NRL-sIgE concentration in $\mathrm{kUa} / \mathrm{L}$ was not significant $(r=0.34$ and 0.21 ; both $P>0.05$ ). Four sera displayed an IgE response to only one allergen: three responded to rHev b 1 and one to $\mathrm{rHev}$ b 5 in the same relative range as to the composite NRL.

Examining combined group data, the quantity of sIgE to the individual Hev b specificities showed a slightly different distribution than the prevalence (see Table $2 \mathrm{~b}$; columns 2 and 3). IgE specific for rHev b 5 was quantitatively the highest in concentration, followed by IgE antibody levels reactive with $\mathrm{rHev} \mathrm{b} 3, \mathrm{rHev}$ b 6.01 and $\mathrm{rHev} \mathrm{b} 1$. The median levels of sIgE to nHev b 2, rHev 7.02, rHev b 11 and nHev b 13 were lower and comparable with each other. In contrast, levels of IgE antibody reactive with $\mathrm{rHev} \mathrm{b} 8$ and $\mathrm{rHev}$ b 12 were very low $(0.46-1.67 \mathrm{kUa} / \mathrm{L})$. In all five sera where IgE anti-rHev b 11 was detected, higher levels of sIgE to $\mathrm{rHev}$ b 6.01 were measured.

When comparing the IgE antibody levels between symptomatic and non-symptomatic SB patient groups (Table 2b), the composite NRL-sIgE levels were not significantly different (symptomatic SB, median: $15.6 \mathrm{kUa} / \mathrm{L}$; range $0.66->100 \mathrm{kUa} / \mathrm{L}$ vs. non-symptomatic SB; median: $7.7 \mathrm{kUa} / \mathrm{L}$; range 0.69-50.4 kUa/L). Significant differences were, however, observed between symptomatic and nonsymptomatic SB patients when IgE reactivities to nHev b 2 $(P<0.05)$ and rHev b $6.01(P<0.01)$ were examined (Table $2 b)$. In both groups, more than $50 \%$ of the sera were positive for IgE-anti-rHev b 1, 3, 5 and nHev b 13. Only in the symptomatic group a pronounced IgE response was detected to nHev b 2 and $\mathrm{rHev}$ b 6.01. In both the symptomatic and non-symptomatic groups, the sIgE responses to rHev b 5 were high. IgE specific for $\mathrm{rHev}$ b 8 was only measured in two symptomatic SB patients; both were 
Table 2b. Prevalence and quantitative levels of specific IgE levels to individual latex allergens in patients with SB with and without symptoms

\begin{tabular}{|c|c|c|c|c|c|c|}
\hline Allergen & $\begin{array}{l}\text { No. of patients } \\
(n=31) \text { with } \\
\text { sIgE }>0.35 \mathrm{kUa} / \mathrm{L} \\
(\%)\end{array}$ & $\begin{array}{l}\text { Mean } \pm \text { SD of } \\
\text { sIgE }>0.35 \mathrm{kUa} / \mathrm{L} \\
\text { (median; range) }\end{array}$ & $\begin{array}{l}\text { No. of patients } \\
\text { with latex-related } \\
\text { symptoms ( } n=19) \\
\text { with sIgE } \\
>0.35 \mathrm{kUa} / \mathrm{L}(\%)\end{array}$ & $\begin{array}{l}\text { Mean } \pm S D \text { of } \\
\text { sIgE }>0.35 \mathrm{kUa} / \mathrm{L} \\
\text { in patients } \\
\text { with latex- } \\
\text { related symptoms } \\
\text { (median; range) }\end{array}$ & $\begin{array}{l}\text { No. of patients } \\
\text { without l } \\
\text { atex-related } \\
\text { symptoms }(n=12) \\
\text { with sIgE } \\
>0.35 \mathrm{kUa} / \mathrm{L}(\%)\end{array}$ & $\begin{array}{l}\text { Mean } \pm \text { SD of sIgE } \\
>0.35 \mathrm{kUa} / \mathrm{L} \\
\text { in patients without } \\
\text { latex-related } \\
\text { symptoms } \\
\text { (median; range) }\end{array}$ \\
\hline rHev b 1 & 25 (80.6) & $\begin{array}{l}9.1 \pm 13.7 \\
\quad(3.8 ; 0.47-48.8)\end{array}$ & $16(84.2)$ & $\begin{array}{l}6.6 \pm 8.0 \\
\quad(4.7 ; 1.06-33.1)\end{array}$ & $9(75)$ & $\begin{array}{l}13.5 \pm 20.1 \\
\quad(3.3 ; 0.47-48.8)\end{array}$ \\
\hline nHev b 2 & $18(66.7)^{*}$ & $\begin{array}{l}4.4 \pm 3.8 \\
\quad(3.7 ; 0.45-13.95)\end{array}$ & $15(83.3)^{\dagger, \ddagger}$ & $\begin{array}{l}4.6 \pm 4.0 \\
\quad(3.3 ; 0.46-13.95)\end{array}$ & $3(30.0)^{\S}$ & $\begin{array}{l}3.3 \pm 2.5 \\
\quad(4.7 ; 0.45-4.73)\end{array}$ \\
\hline rHev b 3 & $18(58.1)$ & $\begin{array}{l}18.3 \pm 26.6 \\
\quad(7.0 ; 0.47-92.6)\end{array}$ & 11 (57.9) & $\begin{array}{l}20.6 \pm 30.1 \\
\quad(8.1 ; 0.47-92.9)\end{array}$ & 7 (58.3) & $\begin{array}{l}14.6 \pm 21.5 \\
\quad(4.8 ; 0.64-60.7)\end{array}$ \\
\hline rHev b 5 & 16 (51.6) & $\begin{array}{l}31.7 \pm 32.1 \\
\quad(20.7 ; 0.37 \text { to }>100)\end{array}$ & $10(52.6)$ & $\begin{array}{l}41.7 \pm 37.0 \\
\quad(35.5 ; 1.3 \text { to }>100)\end{array}$ & $6(50)$ & $\begin{array}{l}15.0 \pm 9.0 \\
\quad(16.9 ; 0.37-24.6)\end{array}$ \\
\hline rHev b 6.01 & $15(48.4)$ & $\begin{array}{l}12.4 \pm 13.5 \\
(4.6 ; 0.64-42.1)\end{array}$ & $13(68.4)^{\top}$ & $\begin{array}{l}13.3 \pm 14.3 \\
\quad(4.6 ; 0.64-42.1)\end{array}$ & $2(16.7)$ & $\begin{array}{l}6.3 \pm 3.0 \\
\quad(6.3 ; 4.2-8.46)\end{array}$ \\
\hline rHev b 7.02 & $6(20.7)^{\|}$ & $\begin{array}{l}3.2 \pm 2.5 \\
\quad(3.5 ; 0.38-5.8)\end{array}$ & $4(21.1)$ & $\begin{array}{l}4.1 \pm 2.5 \\
\quad(5.1 ; 0.38-5.8)\end{array}$ & $2(33.3)^{\S}$ & $\begin{array}{l}1.3 \pm 1.3 \\
\quad(1.4 ; 0.42-2.3)\end{array}$ \\
\hline rHev b 8 & $2(6.4)$ & $\begin{array}{l}1.1 \pm 0.9 \\
\quad(1.1 ; 0.46-1.67)\end{array}$ & $2(10.5)$ & $\begin{array}{l}1.1 \pm 0.9 \\
\quad(1.1 ; 0.46-1.67)\end{array}$ & $0(0)$ & - \\
\hline rHev b 11 & $5(17.2)^{\|}$ & $\begin{array}{l}4.6 \pm 6.0 \\
\quad(2.7 ; 0.8-15.2)\end{array}$ & $4(22.2)^{\ddagger}$ & $\begin{array}{l}5.5 \pm 6.6 \\
\quad(3.0 ; 0.8-15.2)\end{array}$ & $1(9.1)^{* *}$ & 1.0 \\
\hline rHev b 12 & $5(17.2)^{\|}$ & $\begin{array}{l}0.6 \pm 0.2 \\
\quad(0.6 ; 0.47-0.63)\end{array}$ & $2(10.5)$ & $\begin{array}{l}0.55 \pm 0.11 \\
\quad(0.55 ; 0.47-0.63)\end{array}$ & $3(30)^{\S}$ & $\begin{array}{l}0.6 \pm 0.02 \\
\quad(0.58 ; 0.54-0.58)\end{array}$ \\
\hline nHev b 13 & $18(66.7)^{*}$ & $\begin{array}{l}3.8 \pm 3.4 \\
\quad(2.9 ; 0.53-12.5)\end{array}$ & $13(76.5)^{\dagger \dagger}$ & $\begin{array}{l}4.7 \pm 3.6 \\
\quad(4.2 ; 1.04-12.5)\end{array}$ & $5(50)^{\S}$ & $\begin{array}{l}1.5 \pm 1.3 \\
\quad(1.2 ; 0.53-3.6)\end{array}$ \\
\hline
\end{tabular}

Number of patients tested.

${ }^{*} n=27 ;{ }^{\dagger} \mathrm{nHev}$ b 2 comparison between SB with and without symptoms: $P<0.05 ;{ }^{\ddagger} n=18 .{ }^{\S} n=10 ;{ }^{\natural} \mathrm{rHev} \mathrm{b} 6.01$ comparison between SB with and without symptoms: $P<0.01 ;{ }^{\|} n=29 ;{ }^{* *} n=11 ;{ }^{\dagger \dagger} n=17$; rHev b, recombinant Hevea brasiliensis; nHev b, native Hevea brasiliensis; sIgE, allergenspecific IgE antibody; SB, spina bifida.

atopics. Thus, with the exception of nHev b 2 and $\mathrm{rHev} b$ 6.01 reactivity, levels of IgE antibody to the other Hev b specificities were not useful as risk factors to identify SB patients who might be expected to manifest clinically evident allergic symptoms.

In terms of the qualitative presence of IgE anti-Hev b responses, symptomatic SB patients responded to a mean of six allergens (median; range: 0-8) while non-symptomatic SB patients had detectable IgE antibody to a mean of three allergens (median; range: 1-8). The correlation between the number of IgE antibody Hev allergen specificities present and the quantitative NRL-specific IgE antibody levels was comparably significant in both groups (non-symptomatic: $r=0.79 ; P=0.0025$ vs. symptomatic group: $r=0.56 ; P=0.013$ ). The two sera from symptomatic SB patients with LFS showed IgE reactivity to $\mathrm{rHev} b 1$, $6.01,11$ and nHev b 2, whereas the first serum responded additionally to rHev b 3 and nHev b 13 and the second one to rHev b 5 and 12.

Healthcare worker with latex allergy. The latex-specific IgE antibody profiles for the 104 latex-allergic HCW (Table 3) were different from the profiles of the SB patients, especially with regard to $\mathrm{rHev}$ b 1 and 3 reactivity (each $P<0.0001$ ). In all three HCW groups, the highest IgE antibody response frequency was observed to nHev b 13 (83.2\%), followed by nHev b 2 (73\%), rHev b 6.01and rHev b 5 (both 67\%) and rHev b 7.02 (26.2\%). Differences between countries were not significant. Only sera from several HCW (2.8-12.5\%) were shown to contain IgE antibody specific for $\mathrm{rHev}$ b 1, 3, 8, 9, 10, 11 and 12 (Table 3). All sera were negative for MBP and rHev b 2. The most pronounced quantitative IgE response was specific for rHev b 5 (mean range $15.1-26.7 \mathrm{kUa} / \mathrm{L}$ ) followed by reactivity to $\mathrm{rHev}$ b $6.01(6.2-14.6 \mathrm{kUa} / \mathrm{L})$.

The HCW group produced IgE antibody that reacted with a mean of four individual Hev b allergens (range: 1-12 Hev b specificities). The correlation between the composite NRL-sIgE concentration in $\mathrm{kUa} / \mathrm{L}$ and the qualitative numbers of IgE anti-Hev b allergen specificities that were positive was significant $(r=0.67$; $P<0.0001)$. Of the HCW group, 14 sera $(13.5 \%)$ contained IgE that reacted with only one allergen (seven to rHev b 5, three to rHev b 6.01, three to rHev b 8 and one to $n \mathrm{Hev} b$ 13). These individual IgE anti-Hev b levels were quantitatively comparable with the sIgE concentrations detected 
Table 3. Prevalence and quantitative levels of specific IgE antibody to individual Hev b allergens in latex allergic German $(n=51)$, Portuguese ( $n=21)$ and American $(n=32)$ healthcare workers (HCW)

\begin{tabular}{|c|c|c|c|c|c|c|c|}
\hline \multirow[b]{2}{*}{ Allergen } & \multicolumn{2}{|l|}{ German } & \multicolumn{2}{|l|}{ Portuguese } & \multicolumn{2}{|l|}{ American } & \multirow{2}{*}{$\begin{array}{l}\text { HCW (total, } \\
n=104) \\
\text { no. of } \\
\text { patients with } \\
\text { sIgE }>0.35 \mathrm{kUa} / \mathrm{L} \\
(\%)\end{array}$} \\
\hline & $\begin{array}{l}\text { No. of } \\
\text { patients with } \\
\text { sIgE >0.35 } \\
\text { kUa/L (\%) }\end{array}$ & $\begin{array}{l}\text { Mean } \pm \text { SD } \\
\text { of sIgE } \\
>0.35 \mathrm{kUa} / \mathrm{L} \\
\text { (median; range) }\end{array}$ & $\begin{array}{l}\text { No. of patients } \\
\text { with sIgE } \\
>0.35 \mathrm{kUa} / \mathrm{L}(\%)\end{array}$ & $\begin{array}{l}\text { Mean } \pm \text { SD of sIgE } \\
>0.35 \mathrm{kUa} / \mathrm{L} \\
\text { (median; } \\
\text { range) }\end{array}$ & $\begin{array}{l}\text { No. of patients } \\
\text { with sIgE }>0.35 \\
\mathrm{kUa} / \mathrm{L}(\%)\end{array}$ & $\begin{array}{l}\text { Mean } \pm \text { SD of } \\
\text { sIgE }>0.35 \mathrm{kUa} / \mathrm{L} \\
\text { (median; range) }\end{array}$ & \\
\hline rHev b 1 & $9(17.6)$ & $\begin{array}{l}9.7 \pm 16.7 \\
\quad(3.5 ; 1.2-52.8)\end{array}$ & $1(4.8)$ & 91.3 & $2(6.3)$ & $\begin{array}{l}3.91 \pm 0.9 \\
\quad(3.9 ; 3.3-4.5)\end{array}$ & $12(11.5)$ \\
\hline nHev b 2 & $40(78.4)$ & $\begin{array}{l}3.7 \pm 4.9 \\
\quad(1.6 ; 0.35-24.5)\end{array}$ & $15(71.4)$ & $\begin{array}{l}5.3 \pm 7.7 \\
\quad(1.8 ; 0.56-18.7)\end{array}$ & $21(65.6)$ & $\begin{array}{l}5.9 \pm 10.5 \\
\quad(1.7 ;-0.43 \text { to } 44.1)\end{array}$ & $76(73)$ \\
\hline rHev b 3 & $4(7.8)$ & $\begin{array}{l}4.3 \pm 2.9 \\
\quad(3.9 ; 1.5-8.0)\end{array}$ & $2(10)^{*}$ & $\begin{array}{l}1.6 \pm 1.7 \\
\quad(1.6 ; 0.37-2.8)\end{array}$ & $2(6.3)$ & $\begin{array}{l}3.65 \pm 1.84 \\
\quad(3.65 ; 2.35-4.95)\end{array}$ & $8(7.8)^{\dagger}$ \\
\hline rHev b 5 & $38(74.5)$ & $\begin{array}{l}18.8 \pm 23.5 \\
\quad(9.1 ; 0.37 \text { to }>100)\end{array}$ & 13 (61.9) & $\begin{array}{l}26.7 \pm 36.4 \\
\quad(7.1 ; 0.52 \text { to }>100)\end{array}$ & $19(59.4)$ & $\begin{array}{l}15.1 \pm 18.1 \\
(10.0 ; 0.55-63.7)\end{array}$ & $70(67)$ \\
\hline rHev b 6.01 & $36(70.6)$ & $\begin{array}{l}14.6 \pm 24.3 \\
\quad(6.1 ; 0.5 \text { to }>100)\end{array}$ & $16(76.2)$ & $\begin{array}{l}13.3 \pm 27.3 \\
\quad(3.5 ; 0.6 \text { to }>100)\end{array}$ & $18(56.3)$ & $\begin{array}{l}6.15 \pm 8.2 \\
\quad(2.85 ; 0.49-32.9)\end{array}$ & $70(67)$ \\
\hline rHev b 7.02 & $15(29.4)$ & $\begin{array}{l}6.0 \pm 5.4 \\
\quad(3.6 ; 0.43-17.8)\end{array}$ & $3(15)^{*}$ & $\begin{array}{l}6.9 \pm 11.2 \\
\quad(0.5 ; 0.4-19.9)\end{array}$ & $9(28.1)$ & $\begin{array}{l}2.44 \pm 3.2 \\
\quad(1.7 ; 0.55-10.7)\end{array}$ & $27(26.1)^{\dagger}$ \\
\hline rHev b 8 & $7(13.7)$ & $\begin{array}{l}5.4 \pm 3.8 \\
\quad(6.6 ; 1.4-11.1)\end{array}$ & $1(4.8)$ & 0.53 & $5(15.6)$ & $\begin{array}{l}4.4 \pm 4.8 \\
\quad(1.8 ; 0.55-10.2)\end{array}$ & $13(12.5)$ \\
\hline rHev b 9 & $1(2.0)$ & 4.0 & $1(5)^{*}$ & 0.6 & 0 & - & $2(1.8)^{\dagger}$ \\
\hline rHev b 10 & $1(2.0)$ & 4.0 & $1(5)^{*}$ & 0.44 & $1(3.1)$ & 0.98 & $3(2.8)^{\dagger}$ \\
\hline rHev b 11 & $12(23.5)$ & $\begin{array}{l}5.4 \pm 10.3 \\
\quad(1.4 ; 0.38-36.5)\end{array}$ & $1(5)$ & 31.9 & $0^{\ddagger}$ & - & $13(12.5)$ \\
\hline rHev b 12 & $9(17.6)$ & $\begin{array}{l}0.49 \pm 0.11 \\
\quad(0.47 ; 0.36-0.67)\end{array}$ & $1(7.1)^{\S}$ & 0.52 & $0^{\top}$ & - & $10(10.2)^{\|}$ \\
\hline nHev b 13 & 44 (86.3) & $\begin{array}{l}4.6 \pm 5.5 \\
\quad(2.3 ; 0.39-24.2)\end{array}$ & $12(100)^{* *}$ & $\begin{array}{l}7.1 \pm 9.9 \\
(1.6 ; 0.37-30.6)\end{array}$ & 23 (71.9) & $\begin{array}{l}5.74 \pm 8.3 \\
\quad(2.1 ; 0.46-33.6)\end{array}$ & $79(83.2)^{\dagger \dagger}$ \\
\hline
\end{tabular}

${ }^{*} n=20 ;{ }^{\dagger} n=103 ;{ }^{\ddagger} P=0.0026 ;{ }^{\S} n=14 ;{ }^{\top} P=0.011$ (comparison between German and United States); $n=97 ;{ }^{* *} n=12 ;{ }^{\dagger} n=95$.

nHev b, native Hevea brasiliensis; rHev b, recombinant Hevea brasiliensis.

in $\mathrm{kUa} / \mathrm{L}$ to the composite NRL (k82s). This suggests that the complete immune response to latex involved $\operatorname{IgE}$ antibody that reacted to only that particular $\mathrm{Hev} b$ specificity.

Specific sIgE responses to $\mathrm{rHev} 6.01$ and $\mathrm{rHev}$ b 11 showed a significant correlation $(r=0.80 ; P<0.0001)$. All the 13 sera with detectable IgE anti-rHev b 11 had higher sIgE concentrations to $\mathrm{rHev} b$ 6.01. In addition, there was a significant correlation between $\mathrm{rHev} b$ 6.01 and nHev b $13(r=0.60 ; P<0.0001)$, although isolated responses were also observed to each of the two allergens.

Patients with multiple surgeries. In this group of patients, only $\mathrm{nHev} \mathrm{b} 2$ and 13 seem to be principal Hev b-allergen specificities ( $\geqslant 50 \%$ ); IgE responses to $\mathrm{rHev}$ b 1, 3, 5 and 6.01 were present, but in $<50 \%$ of the MS patients (Table 2a). Quantitatively the sera from the MS patients contained the highest amounts of IgE specific for $\mathrm{rHev} b 5$. No IgE antibody responses were detected in this group to $\mathrm{rHev} \mathrm{b}$ 2, 7.02, 8, 9, 10, 11 and MBP.
Comparison of different natural rubber latex ImmunoCAPs ${ }^{T M}$ for latex diagnosis

In addition to the testing with the composite NRL Immuno$\mathrm{CAP}^{\mathrm{TM}} \mathrm{k} 82 \mathrm{~s}$ that was supplemented with $\mathrm{rHev} \mathrm{b} 5$, the German HCW sera only were analysed using the NRL ImmunoCAP ${ }^{\mathrm{TM}} \mathrm{k} 82$ without $\mathrm{rHev}$ b 5 supplementation and an rHev b-mix ImmunoCAP ${ }^{\mathrm{TM}}$ containing rHev b 1, 5, 6.01 and 8 . The correlation between the qualitative IgE antibody results obtained with $\mathrm{k} 82$ and $\mathrm{k} 82 \mathrm{~s}$ ImmunoCAPs ${ }^{\mathrm{TM}}$ was $0.92(P<0.0001)$. While all sera were positive to both the k82 abd k82s, 41\% of sera contained IgE antibody specific for Hev $\mathrm{b} 5$ that was underestimated with the k82 Immuno$\mathrm{CAP}^{\mathrm{TM}}$. The k82s, which was supplemented with rHev b 5, detected higher levels of IgE anti-NRL in these sera [median values: 9.2 (k82) vs. $11.8 \mathrm{kUa} / \mathrm{L}(\mathrm{k} 82 \mathrm{~s})]$. In most of these sera, the sIgE response to $\mathrm{rHev} \mathrm{b} 5$ was predominant.

The comparison of IgE antibody results detected in the HCW sera using the k82s and the rHev b-mix Immuno$\mathrm{CAP}^{\mathrm{TM}}$ also correlated well $(r=0.91 ; P<0.0001)$. Interestingly, four sera showed no IgE binding to the rHev b-mix ImmunoCAP ${ }^{\mathrm{TM}}$ despite effective binding to the composite 
k82s ImmunoCAP ${ }^{\mathrm{TM}}$. The IgE immune response in these patients was directed at nHev b 2 and 13 and two of them showed a positive IgE-response to HRP in a comparable level to the reaction seen with the k82s ImmunoCAP ${ }^{\mathrm{TM}}$.

We assessed the potential of different combinations of recombinant Hev b allergens to detect IgE antibodies in individuals suspected of NRL sensitivity. The data in Tables $2 \mathrm{a}$ and $\mathrm{b}$ showed that a combination of $\mathrm{rHev} \mathrm{b} 1$ and 3 was able to recognize $87 \%$ of all SB patients with latex sIgE. This included 95\% of SB patients with latexrelated symptoms and 83\% who were asymptomatic. However, only 30\% of the latex-allergic MS patients and 17.6\% of latex-allergic HCW could be detected with Hev b 1 and Hev b 3 alone on the allergosorbent. In contrast, a combination of rHev b 5 and 6.01 was able to detect IgE antibody in $92.2 \%$ of all HCW, $71 \%$ of the SB patients with latex sIgE and 70\% of the MS patients. Combining rHev b 5, 6.01 and nHev b 2 on the allergosorbent permitted identification of $98 \%$ of NRL-allergic HCW and 77\% of SB patients (89\% of SB with and 58\% without latex-related symptoms). A mix of rHev b 5, 6.01 and nHev b 13 on the allergosorbent would result in the correct identification of $100 \%$ of the latex-allergic HCW and an enhanced detection rate of SB patients (80.1\% in the total group, $89 \%$ in the symptomatic and $67 \%$ in the asymptomatic group).

\section{Impact of cross-reactive carbohydrate determinants for latex allergy}

Only 12 of the 145 sera (8.3\%; seven German and five American HCW) contained SIgE that reacted with the carbohydrate determinants on HRP (median: $0.67 \mathrm{kUa} / \mathrm{L}$; range $0.37-7.95 \mathrm{kUa} / \mathrm{L}$ ). In four cases the HRP-specific IgE levels were similar to those detected with the k82s (NRL) allergosorbent. The other eight sera displayed very low antiHRP concentrations when compared with the NRL-sIgE concentrations. All these 12 sera displayed sIgE to $\mathrm{nHev} b$ 2 as well. Inhibition studies (Table 4) performed with 10 sera (six with sIgE to $\mathrm{HRP}>1.0 \mathrm{kUa} / \mathrm{L}$ and four without HRP-sIgE) using NRL ImmunoCAPs ${ }^{\mathrm{TM}}$ as the solid phase and HRP as the inhibitor produced significant inhibition $>20 \%$ in only two sera. These two sera were predominantly positive for IgE antibody specific for $n \mathrm{Hev}$ b 2 and/or 13 while IgE immunoreactivity to the recombinant latex allergens was absent or weak (rHev b 5, 7.02, 12).

In two cases with a positive IgE antibody response to nHev b 2 and HRP ( $\geqslant 1.0 \mathrm{kUa} / \mathrm{L})$ and two other cases without HRP-sIgE, nHev b 2 was used as the solid phase and inhibition was performed with soluble HRP. Both sera with IgE anti-nHev b 2 and HRP showed only minor but relevant inhibition (36-37\%) while in the cases without HRP-sIgE no inhibition $(<20 \%)$ was observed. These data confirmed the presence of CCDreactive IgE antibody that may have been associated with IgE binding to nHev b 2.

\section{Discussion}

We conclude from the data in this study that the available panel of recombinant and nHev b allergens was effective in assessing the heterogeneity of the IgE antibody response for Hev b allergens in high-risk-populations. The analyses have provided an insight into the prevalence of the IgE antibodies of different Hev b specificities. This in turn has allowed us to identify which Hev b allergen specificities may be considered clinically most predominant. Moreover, for the first time, these analyses were performed with the ImmunoCAP ${ }^{\mathrm{TM}}$ System that provides quantitative and reproducible measures of $\mathrm{Hev}$ b-specific IgE antibody responses in occupationally exposed HCW and exposed children with SB. Because rHev b 2 [9] and rHev 13 (data not shown) were previously shown to have no relevant IgE-binding epitopes, we used isolated native allergens to complete the Hev b spectrum to assess the utility of a 'component-resolved latex diagnostic'. This study documents the heterogeneity of the sensitization profile by providing qualitative IgE anti-Hev b reactivity frequencies and quantitative IgE anti-Hev b concentrations.

\section{Spina bifida and multiple surgeries patients: Hevea brasiliensis 1 and 3 are the major latex allergens in spina bifida patients}

Together with Hev b 2, 5 and 13, Hev b 1 and 3 are the major latex allergens that induce IgE antibodies in children with SB who become sensitized primarily through mucosal exposure during surgery and maintenance with urinary catheters. Interestingly, these are more modestly important ( $>20$ and $<50 \%$; Hev b 1) and minor (Hev b 3) allergens in patients who become exposed through MS patients. Variations between the SB and MS groups most likely stem from different latex exposures occurring with the different types of surgeries.

Recently, Lee et al. [24] described that hevamine and Hev b 1 are the major allergens in Taiwanese medical workers. In the past, hevamine has been considered as a minor latex allergen in western countries, but it seems to be more important in other areas of the world. While the diet, lifestyle and exposure conditions (e.g. different brands of gloves) are not similar between Germany and Portugal, no geographically relevant differences in their IgE responses to NRL were observed between German and Portuguese SB patients. With the exception of two sera, all Hev b 3-positive individuals produced sIgE reactive with $\mathrm{rHev} b \mathrm{1}$. These data support the observations of Wagner et al. [25], that the insoluble particle-bound allergens Hev b 1 and 3 contain similar IgE epitopes and that the suspected route of sensitization (mucosal) is the same for both. Based on this insolubility, both allergens are much harder to aerosolize, and their sensitization process thus seems to require direct contact of latex with blood or 
Table 4. Inhibition of specific IgE to NRL or nHev b 2 in the presence of HRP

\begin{tabular}{|c|c|c|c|c|c|c|c|c|}
\hline \multirow[b]{2}{*}{ Patient } & \multirow[b]{2}{*}{$\begin{array}{l}\text { sIgE to } \\
\text { NRL (kU/L) }\end{array}$} & \multirow[b]{2}{*}{$\begin{array}{l}\text { sIgE to } \\
\text { HRP (kU/L) }\end{array}$} & \multirow[b]{2}{*}{$\begin{array}{l}\text { sIgE to } \\
\text { bromelain }(\mathrm{kU} / \mathrm{L})\end{array}$} & \multicolumn{2}{|l|}{ Inhibition } & \multirow[b]{2}{*}{$\begin{array}{l}\text { sIgE to nHev } \\
\text { b } 2(\mathrm{kU} / \mathrm{L})\end{array}$} & \multicolumn{2}{|l|}{ Inhibition } \\
\hline & & & & $\begin{array}{l}\text { sIgE to NRL in } \\
\text { the presence of } \\
\text { HRP }(k U / L)\end{array}$ & $\begin{array}{l}\% \\
\text { inhibition }\end{array}$ & & $\begin{array}{l}\text { sIgE to nHev b } 2 \text { in } \\
\text { the presence of } \\
\mathrm{HRP}(\mathrm{kU} / \mathrm{L})\end{array}$ & $\begin{array}{l}\text { \% } \\
\text { inhibition }\end{array}$ \\
\hline 1 & $6.94^{*}$ & 7.95 & 7.79 & 6.18 & 11 & 3.88 & 2.45 & 37 \\
\hline 2 & $4.74^{\dagger}$ & 1.47 & 1.38 & 4.89 & 0 & 4.94 & 3.15 & 36 \\
\hline $3^{\ddagger}$ & 0.64 & 0.74 & 3.95 & ND & ND & 0.37 & ND & ND \\
\hline $4^{\S}$ & 1.62 & 2.64 & 0.51 & 0.35 & 79 & 0.49 & 0.08 & 84 \\
\hline $5^{\circ}$ & 2.55 & 1.5 & 1.78 & 1.08 & 58 & 1.82 & ND & ND \\
\hline 6 & $4.08^{*}$ & 0.41 & 3.43 & 3.92 & 4 & 3.5 & ND & ND \\
\hline 7 & 2.83 & 0.4 & 0.53 & 2.5 & 12 & 0.38 & ND & ND \\
\hline 8 & 16.5 & $<0.35$ & $<0.35$ & 16.3 & 0 & $<0.35$ & ND & ND \\
\hline 9 & 3.56 & $<0.35$ & $<0.35$ & 3.16 & 12 & 2.01 & 1.96 & 2 \\
\hline $10^{\|}$ & 2.16 & $<0.35$ & $<0.35$ & 2.05 & 6 & 0.97 & 0.78 & 20 \\
\hline $11^{* *}$ & 3.22 & $<0.35$ & $<0.35$ & 3.14 & 2 & $<0.35$ & ND & ND \\
\hline
\end{tabular}

*Serum diluted; originally $>100 \mathrm{kU} / \mathrm{L}$.

${ }^{\dagger}$ Serum diluted; originally $38.6 \mathrm{kU} / \mathrm{L}$.

${ }^{\ddagger}$ Positive to nHev b 13, nHev b 2.

${ }^{\S}$ Positive to nHev b 2, nHev b 13, weak positive response to rHev b 7.02, rHev b 12.

"Positive to nHev b 2, weak positive response to rHev b 5 .

"Positive to nHev b 2, nHev b 4 and nHev b 13.

**Positive to nHev b 2, rHev b 6.01 and nHev b 13.

nHev b, native Hevea brasiliensis; rHev b, recombinant Hevea brasiliensis; sIgE, allergen-specific IgE antibody; ND, not done; NRL, natural rubber latex; HRP, horseradish peroxidase.

mucosal surfaces, which occurs during surgery. Although the sensitizing contact to latex (during surgeries) seems to be the same for SB and MS patients, an apparent diseasespecific association of Hev b 1 and 3 exists; in MS patients with a comparable frequency of surgeries, Hev b 1 and 3 were less immunogenic. A comparable observation was made for Spanish non-SB multi-operated children [26]. These two results challenge the concept that Hev b 1 is the most important allergen in patients exposed through MS. Even though statistically elevated levels of Hev b 1 and/or 3 sIgE are characteristic of SB patients and are therefore able to discriminate between SB patients and HCW, discrimination between latex allergic and latex sensitized, but asymptomatic, SB patients cannot be achieved on the basis of IgE antibodies specific for these two allergens. In addition, the NRL-sIgE levels did not allow the discrimination of these two groups either. In the current study, however, IgE specific for $n \mathrm{Hev}$ b 2 and $\mathrm{rHev}$ b 6.01 was significantly more frequent in symptomatic SB patients and thus the detection of IgE specific for these two allergens may allow on to discriminate between latex sensitization and clinical relevant latex allergy in SB patients. In contrast to other patients with latex-specific IgE but without latex-related clinical symptoms [27], e.g. patients with Hymenoptera venom allergy [28], CCDs do not appear to be relevant for SB patients. This conclusion is based on the absence of detectable IgE responses to HRP in the sera from children with SB. In asymptomatic SB patients, the NRL-sIgE response occurs from contact to latex devices during multiple operations and not as a result of cross-reactivity to other glycosylated allergens. Thus, the appearance of CCD cross-reactive IgE anti-NRL may be useful as a predictive marker for the development of symptoms if latex exposure continues.

Recently, studies with limited numbers of available latex allergens $[15,29]$ have underestimated the importance of Hev b 2, 5, 6.01 and 13 as additional important allergens for SB patients. The high Hev b 5-sIgE levels detected in the present study were remarkable and they identified Hev b 5 as one of the most potent NRL allergens for SB patients.

With the exception of Hev b 1 and 3, no other IgE antiHev b specificity could be identified that discriminate latex-symptomatic SB patients from latex-allergic HCW.

Healthcare workers: four allergens play the dominant role in sensitizing latex-allergic healthcare workers in different geographical areas

Data from the current study confirm that Hev b 2, 5, 6.01 and 13 are the major allergens involved in sensitizing HCW in industrialized countries (e.g. Germany, Portugal and the United States). Moreover, Hev b 1 and 3 are of minor relevance since $<20 \%$ of the HCW have positive IgE antibody responses to these allergens. Hev b 7.02 appears to be of an intermediate relevance and shows no association to the atopic status or the presence of the LFS. These data confirm our previous preliminary results on 
the limited importance of rHev b 7.02 [23] in a smaller patient group.

Hev b 11.0102, the Hevea latex class I chitinase is derived from Hevea leaves [8]. It displayed a minor relevance as latex allergen and was only recognized in sera with sIgE responses to $\mathrm{rHev}$ b 6.01. Although no inhibition experiments have been performed to prove the cross-reactivity so far, this strong association could be based on the high degree of sequence identity between the hevein domain of Hev b 6.01 (Hev b 6.02) and Hev b 11 [30].

\section{The role of carbohydrate determinants in latex allergy}

Among latex proteins, the two major allergens Hev b 2 and 13 are known to be extensively glycosylated. We demonstrated previously [9] that the recombinant unglycosylated form of Hev b 2 that is produced in E. coli was not able to bind specific IgE. Nevertheless, the IgE reactivity of the glycosylated latex allergens seems not to be restricted to their glycan chains. Data from the current study demonstrate that only a minority of sera (6.2\%) recognized CCDs and only in two sera is a noteworthy inhibition of NRL and Hev b 2 sIgE with HRP. In the case of these glycosylated allergens, a combined IgE-binding site is conceivable, composed of a peptide and a carbohydrate epitope on the same allergen molecule. In contrast to subjects in the current study who have a verified latex induced latex sensitization, some allergic patients are not originally sensitized to latex allergen [27]. Thus carbohydrate epitopes may be recognized IgE in the serum of these patients, which can be highly cross-reactive. The clinical relevance of a positive IgE antibody response to these CCDs has been questioned. If the patient is in fact sensitized to a latex allergen, then the presence of glycan-specific IgE antibody in addition to an anti-peptide IgE can result in a higher quantitative result. Such a result may suggest a more severe sensitization than might actually be the case. A positive IgE anti-CCD result means that an in vitro IgE measurement specific for an allergen that contains these CCD structures could be due partly or completely to the glycoepitopes present. In these cases, the clinical relevance must be evaluated within the context of the patient's symptoms.

\section{The relevance of the native Hevea brasiliensis 2 and 13}

In a current study [31], the role of glycosylation in IgE antibody recognition of $\mathrm{Hev}$ b 2 was evaluated using periodate-treated nHev b 2 . These data support the conclusion that the protein epitopes of Hev b 2 are more frequently recognized by allergic subjects than by subjects who are non-clinically allergic but sensitized. The absence of carbohydrate in the recombinant proteins may explain the discrepancy between the IgE antibody results detected with the native vs. the recombinant species; however, other factors such as structural conformation of the molecules may also have led to this result [5]. Palosuo et al. [32] have reported that only $17-18 \%$ of sera of Finnish NRL-allergic patients contained IgE antibody reactive with extensively purified Hev b 13 and 2. In contrast, the prevalence of IgE antibodies in the same sera to Hev b 5 and 6.01 was $27 \%$ and $54 \%$, respectively. Compared with our data, their prevalence of sIgE antibodies to these four allergens was in general lower. This may be due to differences between the study groups providing sera and the source (recombinant vs. native) and the extent of purification of the allergens. In contrast to recombinant allergens, the purification steps for native allergens that are isolated from complex mixtures of various allergens have crucial steps and contamination with small amounts of other proteins such as Hev b 6.02 may influence the analyses such as those of the prevalence of IgE antibody responses [33]. Although our data demonstrated a correlation between rHev b 6.01 and $\mathrm{nHev}$ b 13 ( $r=0.64)$, separate IgE antibody responses to each of these two allergens were observed.

\section{Improvement of diagnostic methods for latex allergy}

Our results confirmed previous data [34] that the supplementation of the standard NRL ImmunoCAP ${ }^{\mathrm{TM}}$ with $\mathrm{rHev}$ b 5 improved the diagnostic sensitivity of the Phadia ImmunoCAP ${ }^{\mathrm{TM}}$. As previously shown [35], re-analysis of 16 sera from symptomatic patients with negative IgE response to the k82 (without rHev b 5 supplemented) resulted in eight sera turning positive for IgE anti-latex when they were tested with the rHev b 5-supplemented reagent (k82s). The remaining eight sera remained negative and did not recognize any of the single latex allergens available at present. A mixture of four recombinant allergens also improved the in vitro NRL-sIgE determination compared with the k82, but it was less efficient than the NRL preparation supplemented with $\mathrm{rHev} \mathrm{b}$ 5. The diagnostic sensitivity of the $\mathrm{rHev} b$-mix ImmunoCAP ${ }^{\mathrm{TM}}$ was insufficient especially with sera containing an isolated or dominant response to nHev b 2 or 13 . Moreover, Hamilton et al. have reported that the addition of Hev b 5 to the NRL latex improved the reagent's diagnostic sensitivity when sera were evaluated from latex-allergic patients who had positive skin tests. Interestingly, the diagnostic sensitivity increased 10\% with the Hev b 5supplemented NRL-ImmunoCAP ${ }^{\mathrm{TM}}$ while it is the diagnostic specificity of the ImmunoCAP ${ }^{\mathrm{TM}}$ system remained the same [36].

In conclusion, the report provides the first comprehensive evaluation of the sensitization profiles of latexallergic healthcare workers and patients with SB using a complete set of Hev b allergens. Hev b 2, 5, 6.01 and 13 were identified as major allergens for both HCW and SB while Hev b 1 was additionally identified as a major 
allergen for SB. The results are consistent with those of previous studies [37] using a more limited repertoire in skin testing. These allergens are a must for inclusion in both diagnostic in vitro and in vivo latex reagents. Furthermore, Hev b 7, 8, 9, 10, 11 and 12 which have heretofore not been considered seriously, also need to be present and are useful in evaluating cross-reactivity in select case of latex allergy.

\section{Acknowledgements}

We thank Ursula Meurer and Christina Fleischer for their skilful technical assistance and Dr Paul Degens for his statistical support.

This study was supported by the HVBG (Central Federation of the Statutory Accident Insurance Institutions in Industry and Trade; BGFA project All 10), St Augustin, Germany, and grant \# R01-Al-43654 from the National Institutes of Health in Bethesda, MD, USA.

\section{References}

1 Kurup VP, Alenius H, Kelly KJ, Castillo L, Fink JN. A twodimensional electrophoretic analysis of latex peptides reacting with IgE and IgG antibodies from patients with latex allergy. Int Arch Allergy Immunol 1996; 109:58-67.

2 Posch A, Chen Z, Wheeler C, Dunn MJ, Raulf-Heimsoth M, Baur $\mathrm{X}$. Characterization and identification of latex allergens by twodimensional electrophoresis and protein microsequencing. J Allergy Clin Immunol 1997; 99:385-95.

3 Yagami T, Haishima Y, Tsuchiya T, Tomitaka-Yagami A, Kano H, Matsunaga K. Proteomic analysis of putative latex allergens. Int Arch Allergy Immunol 2004; 135:3-11.

4 Allergen Nomenclature. I.U.I.S. Allergen Nomenclature SubCommittee. Available from: http//www.allergen.org

5 Yeang H-Y. Natural rubber latex allergens: new developments. Curr Opin allergy Clin Immunol 2004; 4:99-104.

6 Rihs HP, Chen Z, Schumacher S et al. Recombinant Hev b 1: large-scale production and immunological characterization. Clin Exp Allergy 2000; 30:1285-92.

7 Rihs HP, Chen Z, Rozynek P, Cremer R. Allergenicity of r Hev b 10 (manganese-superoxid dismutase). Allergy 2001; 56:85-6.

8 Rihs HP, Dumont B, Rozynek P et al. Molecular cloning, purification and IgE-binding of a recombinant class I chitinase from Hevea brasiliensis leaves (rHev b 11.0102). Allergy 2003; 58:246-51.

9 Raulf-Heimsoth M, Rihs HP, Brüning Th. Latex: a new target for standardization. In: Regulatory control and standardization of allergenic extracts, Löwer J, Becker WM, Vieths S, eds. 10th International Paul Ehrlich Seminar, 2. -5. Oktober 2002, Lübeck; Druck- und Verlagshaus Sperlich, Frankfurt am Main, 2003; 94:107-15.

10 Allmers H, Schmengler J, Skudlik C. Primary prevention of natural rubber latex allergy in the German health care system through education and intervention. J Allergy Clin Immunol 2002; 110:318-23.
11 Reunala T, Alenius H, Turjanmaa K, Palosuo T. Latex allergy and skin. Curr Opin Allergy Clin Immunol 2004; 4:397-401.

12 Wagner S, Breiteneder H. Hevea brasiliensis latex allergens: current panel and clinical relevance. Int Arch Allergy Immunol 2005; 136:90-7.

13 Rolland JM, Drew AC, O'Hehir RE. Advances in development of hypoallergenic latex immunotherapy. Curr Opin Allergy Clin Immunol 2005; 5:544-51.

14 Sastre J, Raulf-Heimsoth M, Rihs HP et al. IgE reactivity to latex allergens among sensitized healthcare workers before and after immunotherapy with latex. Allergy 2006; 61:206-10.

15 Raulf-Heimsoth M, Rozynek P, Lundberg M et al. Individual latex allergen sensitization profiles in spina bifida patients and health care workers using a panel of recombinant latex allergens coupled to ImmunoCAP. J Allergy Clin Immunol 2002; 109:S283.

16 Yip L, Hickey V, Wagner B et al. Skin prick test reactivity to recombinant latex allergens. Int Arch Allergy Immunol 2000; 121:292-9.

17 Raulf-Heimsoth M, Wirtz C, Papenfuss F, Baur X. Nasal lavage mediator profile and cellular composition of nasal brushing material during latex challenge tests. Clin Exp Allergy 2000; 30:110-21.

18 Arif SA, Hamilton RG, Yusof $\mathrm{F}$ et al. Isolation and characterization of the early nodule-specific protein homologue (Hev b 13), an allergenic lipolytic esterase from Hevea brasiliensis latex. J Biol Chem 2004; 279:23933-41.

19 Sunderasan E, Bahari A, Arif SA, Zainal Z, Hamilton RG, Yeang HY. Molecular cloning and immunoglobulin E reactivity of a natural rubber latex lecithinase homologue, the major allergenic component of Hev b 4. Clin Exp Allergy 2005; 35:1490-5.

20 Sander I, Kespohl S, Merget R et al. A new method to bind allergens for the measurement of specific IgE antibodies. Int Arch Allergy Immunol 2005; 136:39-44.

21 Rihs HP, Ruëff F, Lundberg M et al. Relevance of the recombinant lipid transfer protein of Hevea brasiliensis: IgE-binding reactivity in fruit-allergic adults. Ann Allergy Asthma Immunol 2006; 97:643-9.

22 Rozynek P, Posch T, Baur X. Cloning, expression and characterization of the major latex allergen prohevein. Clin Exp Allergy 1998; 28:1418-26.

23 Rozynek P, Rihs HP, Gaspar Â, Brüning T, Raulf-Heimsoth M. The new Hev b 7.02 iso-allergen from Hevea brasiliensis is an important allergen for health care workers and spina bifida patients. Allergy 2006; 61:508-9.

24 Lee MF, Chen YH, Lin HC, Wan HL, Hwang GY, Wu CH. Identifcation of Hevamine and Hev b 1 as major latex allergens in Taiwan. Int Arch Allergy Immunol 2006; 139:38-44.

25 Scheiner 0, Wagner B, Wagner S et al. Cloning and molecular characterization of Hev b 3, a spina-bifida-associated allergen from Hevea brasiliensis latex. Int Arch Allergy Immunol 1999; 118:311-2.

26 Pamies R, Oliver F, Raulf-Heimsoth M et al. Patterns of latex allergen recognition in children sensitized to natural rubber latex. Pediatr Allergy Immunol 2006; 17:55-9.

27 Mari A, Iacovacci P, Afferni C et al. Specific IgE to cross-reactive carbohydrate determinants strongly affect the in vitro diagnosis of allergic diseases. J Allergy Clin Immunol 1999; 103:1005-11.

28 Jappe U, Raulf-Heimsoth M, Hoffmann M, Burow G, HübschMüller C, Enk A. In vitro hymenoptera venom allergy diagnosis: 
improved by screening for cross-reactive carbohydrate determinants and reciprocal inhibition. Allergy 2006; 61:1220-9.

29 Kurup VP, Sussman GL, Yeang HY et al. Specific IgE response to purified and recombinant allergens in latex allergy. Clin Mol Allergy 2005; 3:11.

30 0'Riordain G, Radauer C, Hoffmann-Sommergruber $\mathrm{K}$ et al. Cloning and molecular characterization of the Hevea brasiliensis allergen Hev b 11, a class I chitinase. Clin Exp Allergy 2002; 32:455-62.

31 Seifert U, Wagner S, Bublin M et al. The role of glycosylation of $\mathrm{nHev} \mathrm{b} 2$, the $\beta$-1,3-glucanase from Hevea brasiliensis latex, in IgE recognition. J Allergy Clin Immunol 2006; 117:S132.

32 Palosuo T, Lehto M, Kotovuori A et al. Prevalence of IgE antibodies to extensively purified Hev b 13 and Hev b 2 in natural rubber latex (NRL) allergic patients. J Allergy Clin Immunol 2004; 113:S77.

33 Raulf-Heimsoth M, Yeang HY, Sander I et al. Is ENSP (Hev b 13) the missing latex allergen to fill the gap in the repertoire of isolated allergens for the determination of sensitization profiles? J Allergy Clin Immunol 2003; 111:S94.

34 Lundberg M, Chen Z, Rihs HP, Wrangsjö K. Recombinant spiked allergen extract. Allergy 2001; 56:794-5.

35 Raulf-Heimsoth M, Yeang HY, Lundberg M, Arif SAM, Brüning Th, Rihs HP. Improvement of the in vitro diagnostic of natural rubber latex allergy. Estimation of cross-reactivity through application of recombinant and natural single allergens. Allergy Clin Immunol Int: J World Allergy Org 2005; (Suppl. 2): 199-201.

36 Hamilton RG, Rossi CE, Yeang HY, Bernstein DI, Biagini R. Latex-specific IgE assay sensitivity enhanced using Hev b 5 enriched latex allergosorbent. J Allergy Clin Immunol 2003; $111: S 174$.

37 Bernstein DI, Biagini RE, Karnani R et al. In vivo sensitization to purified Hevea brasiliensis proteins in health care workers sensitized to natural rubber latex. J Allergy Clin Immunol 2003; 111:610-6. 